\title{
Isolasi dan identifikasi bakteri asam laktat dari pangan fermentasi berbasis ikan (Inasua) yang diperjualbelikan di Maluku-Indonesia
}

\author{
Isolation and identification of lactic acid bacteria from fish-based fermented foods (Inasua) \\ from Maluku-Indonesia
}

\author{
Adde Lolita Octavia Putri ${ }^{1^{*}}$ dan Endang Kusdiyantini ${ }^{1}$ \\ ${ }^{1}$ Laboratorium Bioteknologi, Departemen Biologi, Fakultas Sains dan Matematika Universitas Diponegoro \\ Jl. Prof. H. Soedarto, SH Tembalang, Semarang, Indonesia
}

\begin{abstract}
ABSTRAK
Bakteri asam laktat merupakan bakteri yang bermanfaat bagi kesehatan tubuh dengan memperbaiki keseimbangan mikroflora intestinal. Bakteri Asam Laktat umumnya dapat diisolasi dari makanan fermentasi, buah-buahan, sayur-sayuran dan daging. Inasua adalah produk fermentasi ikan tradisional yang berasal dari Maluku Tengah (pulau Teon, Nila, dan Serua) dimana dalam proses fermentasi dilakukan dalam suhu ruang selama waktu tertentu. Tujuan penelitian ini adalah isolasi dan identifikasi berdasarkan ciriciri morfologi bakteri asam laktat pada inasua. Isolasi Bakteri Asam Laktat dilakukan dengan metode pour plate dan metode streak pada media de Man, Rogosa and Sharpe Agar (MRSA) dan media Nutrient Agar. Kultur dinkubasi pada suhu $37^{\circ} \mathrm{C}$ selama 48 jam. Koloni yang tumbuh diamati ciri-ciri morfologi dan dilakukan pewarnaan GRAM bakteri. Hasil isolasi BAL dari inasua pada media de Man, Ragosa and Sharpe Agar (MRSA) $+\mathrm{CaCO}_{3}$ diperoleh 4 isolat bakteri yaitu INS-A1, INS-A2, INS-A3 dan INS-A4 dan hanya 2 isolat yang memiliki karakteristik sebagai GRAM positif dengan bentuk Bacillus yaitu INS-A2 dan INS-A4. Diduga 2 isolat tersebut adalah isolat Bakteri Asam Laktat. Hasil isolasi pada media Nutrient Agar (NA) terdapat 5 isolat yaitu INS-B1, INSB2, INS B3, INS-B4, INS-B5 yang memiliki karakteristik sebagai GRAM negatif berbentuk Bacillus.
\end{abstract}

Kata kunci: bakteri asam laktat, Inasua, isolasi, identifikasi morfologi

\begin{abstract}
Lactic acid bacteria are beneficial bacteria for the health of the body by improving the balance of the intestinal microflora. Lactic acid bacteria can generally be isolated from fermented foods, fruits, vegetables and meat. Inasua is a traditional fermented fish product originating from Central Maluku (Teon, Nila and Serua islands) wherein the fermentation process is carried out at room temperature for a certain time. The purpose of this study was isolation and identification based on the morphological characteristics of lactic acid bacteria in inasua. Isolation of Lactic Acid Bacteria was carried out using the pour plate method and the streak method on the media de Man, Rogosa and Sharpe Agar (MRSA) and Nutrient Agar media. The culture was incubated at $37^{\circ} \mathrm{C}$ for 48 hours. The growing colonies were observed for morphological characteristics and GRAM staining of bacteria was carried out. The results of isolation of BAL from inasua in the media de Man, Ragosa and Sharpe Agar $(\mathrm{MRSA})+\mathrm{CaCO} 3$ obtained 4 bacterial isolates, namely INS-A1, INS-A2, INS-A3 and INS-A4 and only 2 isolates that have the characteristics of positive GRAM with Bacillus forms, namely INS-A2 and INS-A4. It is suspected that the 2 isolates were isolates of Lactic Acid Bacteria. The results of isolation on Nutrient Agar (NA) media contained 5 isolates namely INS-B1, INS-B2, INS B3, INS-B4, INS-B5 which have characteristics as negative GRAM shaped Bacillus
\end{abstract}

Keywords: lactic acid bacteria, Inasua, isolation, morphological identification

\section{Pendahuluan}

Bakteri Asam laktat (BAL) adalah kelompok bakteri gram positif, katalase negatif dan dapat memproduksi asam laktat dengan cara memfermentasi karbohidrat. Selnya berbentuk kokus, tersusun berpasangan atau berbentuk rantai,

\footnotetext{
* Penulis korespondensi:

E-mail: Ade.lolita98@gmail.com
}

Hak cipta ( 2018, Jurnal Biologi Tropika, e-ISSN 2614-8323 Tersedia online di http://ejournal2.undip.ac.id/index.php/jbt 
tidak bergerak, tidak berspora, anaerob fakultatif, bersifat non motil dan mesofil (Ray, 2004). BAL mempunyai peran utama dalam fermentasi untuk menghasilkan asam pada pangan fermentasi. Asam tersebut dapat menghambat pertumbuhan bakteri-bakteri patogen dan bakteri pembusuk makanan (Smid and Gorris, 2007). BAL termasuk dalam kelompok bakteri baik dan umumnya memenuhi status GRAS ( Generally Recognized as safe ) yaitu aman bagu manusia, sehingga dapat diaplikasikan sebagai agen probiotik (Surono, 2004). Probiotik adalah mikroba menguntungkan dan bermanfaat untuk memperbaiki kesimbangan mikroflora dalam saluran pencernaan dan memberikan pengaruh positif terhadap fisiologi dan kesehatan inangnya (Afrianto dan Liviawaty, 2005).

Di indonesia fermentasi ikan dengan cara pengawetan tradisional dinilai lebih mudah dan murah (Rahayu et al. 1992). Nilai gizi pada makanan fermentasi lebih tinggi dari bahan asal karena mikroba memiliki kemampuan memecah senyawa kompleks menjadi lebih sederhana. Hal tersebut membuat makanan lebih mudah dicerna ( Buckle, 1987). Produk fermentasi secara tradisional dimiliki oleh masing-masing daerah, salah satunya berupa olahan produk ikan fermentasi tradisional yaitu inasua. Inasua berasal dari Pulau Teon, Nila, dan Serua (TNS) di Maluku Tengah yang diasinkan secara basah. Pembuatan inasua dengan cara fermentasi tertutup menggunakan tambahan garam sebagai bahan pengawet dengan konsentrasi 20\%-30\% selama 3 bulan. Pembuatan inasua berbahan dasar ikan laut seperti ikan kakatua, cakalang, kerong-kerong, bobara, ekor kuning dll (Nendissa, 2001). Fermentasi inasua tidak hanya berlangsung secara anaerobik, tapi juga ditambah sumber karbohidrat dari getah kelapa yang mengandung gula sekitar 5-10\% pada $\mathrm{pH}$ netral untuk memperpanjang umur simpan produk (Noonpakdee et al., 2009). Penelitian terhadap produk inasua sangat jarang dilakukan oleh karena itu penelitian terhadap aspek mikrobiologis dan kimiawi dari produk tersebut menjadi sangat penting untuk dilakukan. Aspek mikrobiologis salah satunya mengkaji tentang karakteristik mikroba sehingga perlu dilakukan isolasi dan identifikasi bakteri. Isolasi mikroba yaitu memisahkan satu jenis mikroba dengan mikroba lainnya dari berbagai macam campuran mikroba dengan tujuan untuk mendapatkan biakan murni. Identifikasi mikroba yaitu untuk mengetahui sifat-sifat morfologi, biokimia dan molekuler dari bakteri. Penelitian ini untuk isolasi dan identifikasi morfologi bakteri asam laktat dari produk inasua.

\section{Metodologi}

\subsection{Isolasi Bakteri Asam Laktat (BAL)}

BAL diisolasi dari sampel inasua menggunakan teknik pengenceran pada media NA dan MRSA Secara aseptik sebanyak 1 gram inasua yang berbentuk pasta disuspensikan ke dalam air pengenceran steril. Selanjutnya dilakukan pengenceran $10^{-1}, 10^{-2}, 10^{-3}, 10^{-4}$. Pengenceran bertujuan untuk mendapatkan koloni bakteri yang terpisah ketika ditumbuhkan di medium. Hasil pengenceran ditanam dengan teknik pour plate dalam 5,5 gram MRSA + 0,75 gram $\mathrm{CaCO}_{3}$ dan ditanam juga ke dalam 2,2 NA lalu diinkubasi pada suhu $37^{\circ} \mathrm{C}$ selama 48 jam. Koloni yang tumbuh diambil menggunakan jarum ose dan ditanam kembali di cawan untuk dimurnikan dengan metode streak. Pemurnian dilakukan pada media MRSA $+\mathrm{CaCO}_{3}$ dan diinkubasi kembali pada suhu $37^{\circ} \mathrm{C}$ selama 48 jam. Pemurnian ini dilakukan sampai terbentuk koloni yang tumbuh terpisah atau tunggal dari bakteri tersebut. Setiap isolat bakteri asam laktat diberi kode isolat untuk penamaan. Isolat yang menghasilkan zona bening lalu digunakan untuk identifikasi lebih lanjut dan juga ditumbuhkan dalam MRSB lalu di pindah ke media miring sebagai kultur stok.

\subsection{Identifikasi Isolat Bakteri Asam Laktat (BAL)}

Proses identifikasi dilakukan dengan mengetahui karakteristik bakteri yang tumbuh. Isolat yang digunakan dalam identifikasi ini adalah biakan murni. Pengamatan morfologi koloni dilakukan secara makroskopis dan mikroskopis. Secara makroskopis meliputi bentuk koloni bakteri, warna koloni, tepi koloni, dan elevasi koloni. Secara mikroskopis diamati bentuk sel, susunan sel dengan mikroskop pada perbesaran 1000x .

Pengecatan GRAM dilakukan pada kultur bakteri umur 24 jam dalam media MRSA. BAL merupakan bakteri GRAM positif yang memberikan wana ungu. Biakan murni BAL diambil 1 ose dan dioleskan pada kaca obyek steril yang telah diberi setetes akuades steril lalu biakan diratakan. Pengecatan ini menggunakan larutan kristal violet (GRAM A) sebagai cat pimer untuk memberi warna mikrooganisme target sehingga berwarna ungu. Larutan lugol iodine (GRAM B) bewarna coklat untuk memperkuat warna dari kristal violet. Alkohol 95\% (GRAM C) untuk 
melunturkan cat sebelumnya dan safranin (GRAM D) untuk memberi warna merah pada mikroorganisme. Selanjutnya dilakukan pengamatan menggunakan mikroskop pada perbesaran 1000x. Bakteri GRAM positif akan bewarna ungu sedangkan bakteri GRAM negatif akan bewarna merah.

\section{Hasil}

\subsection{Isolasi Bakteri Asam Laktat Dari Inasua Menggunakan Media MRSA dan NA}

Isolasi bertujuan untuk mendapatkan biakan murni. Media yang digunakan untuk isolasi BAL adalah media selektif. Media selektif digunakan untuk menumbuhkan dan memelihara bakteri tertentu sehingga dapat menyeleksi BAL dengan sifat khususnya. Media selektif ini hanya dapat ditumbuhi oleh bakteri tertentu. Media yang digunakan untuk isolasi BAL yaitu MRSA $+\mathrm{CaCO}_{3}$. Berdasarkan hasil isolasi yang telah dilakukan didapatkan 4 isolat yang mampu tumbuh dan berkoloni pada media MRSA. Isolat yang tumbuh pada media MRSA dikarakterisasi morfologi koloni yang meliputi bentuk koloni, permukaan koloni, dan warna koloni. Hasil isolasi bakteri pada medium MRSA diperoleh 4 isolat yang memiliki karakteristik koloni yang berbeda.

Berdasarkan hasil isolasi pada media NA didapatkan 5 isolat yang mampu tumbuh dan berkoloni pada media NA. Isolat yang tumbuh dari hasil isolasi inasua dengan media NA dikarakterisasi morfologi pada koloni yang meliputi bentuk, permukaan, tepi dan warna koloni. Menurut Natsir dan Sartini (2006) menyatakan bahwa medium NA adalah medium umum yang memiliki nutrisi untuk pertumbuhan mikrorganisme yang tidak selektif atau mikroorganisme heterotrof. Hasil isolasi bakteri pada medium NA diperoleh 5 isolat yang memiliki karakteristik koloni yang berbeda.

\subsection{Identifikasi Bakteri Asam Laktat Dari Inasua Menggunakan Media MRSA dan NA}

Hasil pengamatan morfologi koloni bakteri secara makroskopis pada media MRSA koloni bakteri berbentuk circular dan punctiform, dengan elevasi convex, flat, dan raised. Tepi koloni bakteri berbentuk entire dan undulate. Bakteri memiliki ciri warna putih dan krem. Koloni bakteri ini memiliki zona bening yang tumbuh pada media MRSA. Diduga semua isolat tersebut adalah ciri-ciri morfologi bakteri asam laktat karena sesuai dengan pernyataan Yoni (2010) yang menyatakan bahwa isolat BAL akan tumbuh ketika diinkubasi pada suhu $37^{\circ} \mathrm{C}$, koloni Lactobacillus memiliki ciri-ciri putih mengkilat, terdapat zona bening disekitar koloni, ukuran koloni 0,5-2mm, berbentuk bulat dan tidak berserat.

Tabel 1. Karakteristik morfologi koloni BAL hasil isolasi dari inasua pada MRSA

\begin{tabular}{cccccc}
\hline \multirow{2}{*}{ No } & \multirow{2}{*}{ Kode Isolat } & \multicolumn{4}{c}{ Morfologi Koloni } \\
\cline { 3 - 5 } & & Bentuk & Elevasi & Tepi & Warna \\
\hline 1. & INS-A1 & circular & convex & entire & Putih \\
2. & INS-A2 & circular & flat & entire & Krem \\
3. & INS-A3 & circular & flat & entire & putih \\
4. & INS-A4 & punctiform & raised & undulate & putih \\
\hline
\end{tabular}

Hasil pengamatan morfologi bakteri secara makroskopis pada media NA koloni bakteri mempunyai bentuk irregular, circular, dan punctiform. Memiliki elevasi raised dan flat. Tepinya berbentuk lobate, undulate, irregular dan rhizoid. Bakteri ini memiliki warna krem dan putih. Diduga isolat ini bukan merupakan isolat Bakteri Asam Laktat, karena isolat BAL memiliki permukaan yang halus dan bentuknya bulat dengan tepi rata, sedangkan pada tabel dapat dilihat tepi dari isolat tersebut bergerigi. Bakteri ini ditumbuhkan pada media NA hanya sebagai pembanding terhadap bakteri yang ditumbuhkan pada media MRSA. NA merupakan media yang tidak selektif, oleh karena itu semua bakteri dapat tumbuh pada media ini. Media NA ini digunakan sebagai media pembanding pertumbuhan bakteri yang tumbuh di media MRSA.

NA merupakan media yang tidak selektif, oleh karena itu semua bakteri dapat tumbuh pada media ini. Hal ini sesuai dengan pendapat Pelczar dan Chan (2008) yang menyatakan bahwa media NA mengandung nutrisi yang dapat mendukung pertumbuhan bakteri. Semua bakteri membutuhkan nutrisi untuk memenuhi kebutuhan hidup yang diperlukan dalam pertumbuhan organisme. Dengan media pertumbuhan dapat diperoleh isolat mikroorganisme menjadi kultur murni. Media NA banyak mengandung sumber Nitrogen sehingga media ini banyak digunakan dalam prosedur bakteriologi untuk pertumbuhan sample pada uji bakteri dan untuk mengisolasi organisme dalam 
kultur murni. Media ini digunakan sebagai pertumbuhan mayoritas dari mikroba yang tidak selektif. Berikut gambar hasil isolasi bakteri asam laktat dari ina sua pada medium NA (Nutrient Agar)

Tabel 2. Karakteristik morfologi koloni BAL hasil isolasi dari inasua pada NA

\begin{tabular}{cccccc}
\hline \multirow{2}{*}{ No. } & \multirow{2}{*}{ Kode Isolat } & \multicolumn{4}{c}{ Morfologi koloni } \\
\cline { 3 - 5 } & & Bentuk & Elevasi & Tepi & Warna \\
\hline 1. & INS-B1 & irregular & raised & lobate & Krem \\
2. & INS-B2 & irregular & flat & undulate & Krem \\
3. & INS-B3 & circular & flat & rhizoid & Krem \\
4. & INS-B4 & punctiform & flat & lobate & Putih \\
5. & INS-B5 & circular & raised & irregular & Putih \\
\hline
\end{tabular}

\subsection{Pewarnaan GRAM}

Pewarnaan GRAM adalah salah satu teknik pewarnaan yang paling penting yang digunakan untuk membedakan antara bakteri GRAM positif dan bakteri GRAM negatif. Prinsip pewarnaan GRAM yaitu saat bakteri diwarnai dengan kristal violet, bakteri GRAM positif akan menyerap zat warna tersebut sehingga bewarna ungu. Sedangkan bakteri GRAM negatif akan melepas zat warna kristal violet setelah dicuci dengan alkohol dan kemudian akan menyerap zat warna terakhir yang diberikan yaitu safranin sehingga bewarna merah. Hal ini sesuai dengan pendapat Waluyo (2008) yang menyatakan bahwa bakteri GRAM positif memiliki dinding sel berupa peptidoglikan yang tebal. Saat peluruhan dengan alkohol, pori-pori dinding sel menyempit karena terjadi dekolorisasi sehingga dinding sel tetap menahan kristal violet. Bakteri GRAM negatif memiliki 3 lapisan dinding sel, sehingga lipid akan tercuci oleh alkohol dan pewarnaan kristal violet akan ikut tercuci. Bakteri GRAM negatif saat diwarnai dengan safranin akan bewarna merah.

Tabel 3. Pewarnaan GRAM Isolat inasua pada media MRSA dan NA

\begin{tabular}{cccccc}
\hline & Media MRSA & \multicolumn{3}{c}{ Media NA } \\
\hline Kode Isolat & GRAM & Bentuk Sel & Kode Isolat & GRAM & Bentuk Sel \\
\hline INS-A1 & $(-)$ & Basil & INS-B1 & $(-)$ & Basil \\
INS-A2 & $(+)$ & Basil & INS-B2 & $(-)$ & Basil \\
INS-A3 & $(-)$ & Basil & INS-B3 & $(-)$ & Basil \\
INS-A4 & $(+)$ & Basil & INS-B4 & $(-)$ & Basil \\
& & & INS-B5 & $(-)$ & Basil \\
\hline
\end{tabular}

Hasil pengamatan karakterisasi mikroskopis secara pewarnaan GRAM pada media MRSA terdapat 2 isolat bewarna ungu dan 2 isolat bewarna merah sedangkan bentuk sel ke 4 isolat adalah basil. Diduga INS-A2 dan INSA4 tergolong bakteri asam laktat karena hasil pewarnaan GRAM adalah GRAM positif. Pengujian GRAM pada isolat di media MRSA juga menunjukkan 2 isolat yang tergolong bakteri GRAM negatif yaitu INS-A1 dan INS-A3. Berdasarkan penelitian menurut Nendissa (2013) menyatakan bahwa inasua difermentasi di dalam larutan garam dan tanpa penambahan inokulum menyebabkan bakteri pembusuk dapat tumbuh pada lingkungan sekitar, sehingga hasil produk inasua kurang baik dengan ciri berlendir, daging lunak dan beraroma amoniak. Kualitas produk ini dapat di perbaiki dengan cara penambahan Pediococcus acidilactici F11 sebagai kultur starter sehingga dapat meningkatkan total bakteri asam laktat (BAL) dan juga dapat menurunkan coliform pada inasua yang dihasilkan. Pertumbuhan BAL sangat tergantung pada kadar garam. Semakin tinggi kansentrasi garam yang diserap oleh daging ikan maka pertumbuhan BAL akan semakin terhambat karena kemampuan BAL itu berbeda-beda.

Hasil pengujian GRAM pada media NA semua isolat bewarna merah dan merupakan bakteri GRAM negatif dengan bentuk sel basil. Diduga isolat yang tumbuh pada media NA bukan isolat BAL. Hal ini sesuai dengan pernyataan Yousef (2003) bahwa bakteri asam laktat merupakan GRAM positif berwarna ungu berbentuk bulat atau batang, tidak membentuk spora, mampu memfermentasi karbohidrat, katalase negatif dan merupakan kelompok mikroaerofilik.

Pengujian GRAM pada media MRSA menunjukkan bahwa isolat INS-A2 dan INS-A4 adalah GRAM positif dan INS-A1 dan INS-A3 adalah GRAM negatif. Isolat INS-A1 dan INS-A3 bewarna merah, berbentuk basil, sedangkan isolat INS-A2 dan INS-A4 bewarna ungu dan berbentuk basil dapat dilihat pada Gambar 1. 

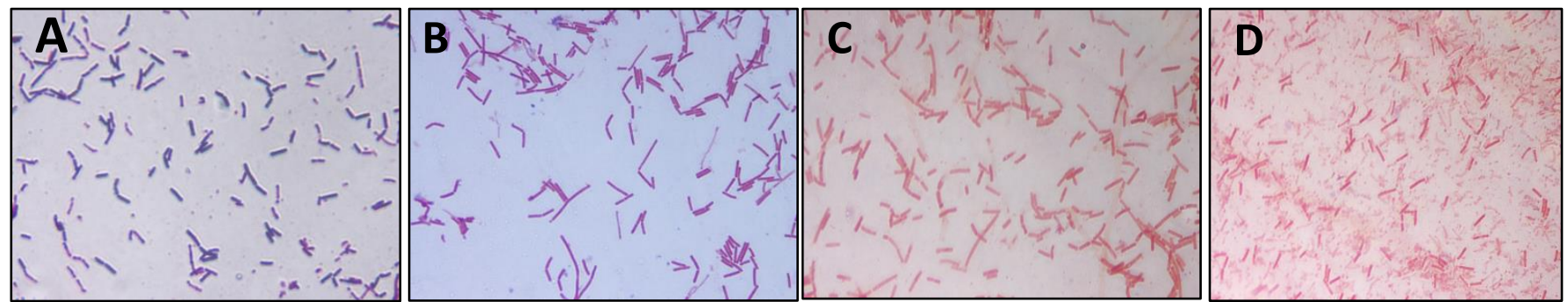

Gambar 1. Pewarnaan Isolat BAL inasua pada MRSA: a. Isolat INS-A2; b. Isolat INS-A4; c. Isolat INS-A1; d. Isolat INS-A3

Berdasarkan uji pewarnaan GRAM, isolat BAL dari inasua pada media MRSA menghasilkan 2 isolat yang memiliki bentuk morfologi basil dengan susunan berantai dan merupakan gram positif. Menurut Acton (2013) BAL yang digolongkan ke dalam famili Lactobacillaceae dengan ciri bakteri GRAM positif dengan bentuk batang, tidak memiliki endospora. Bakteri ini dapat dikelompokkan menjadi dua kelompok, yaitu homofermentatif dan heterofermentatif. Lactobacillus homofermentatif dapat memecah glukosa terutama menjadi asam laktat. Bakteri heterofermentatif dapat memecah glukosa menjadi asam laktat, asam asetat, asam propionat dan etanol.

Pengujian GRAM pada media NA menunjukkan bahwa semua isolat adalah GRAM negatif. Semua isolat bewarna merah, berbentuk basil dapat dilihat pada Gambar 2.
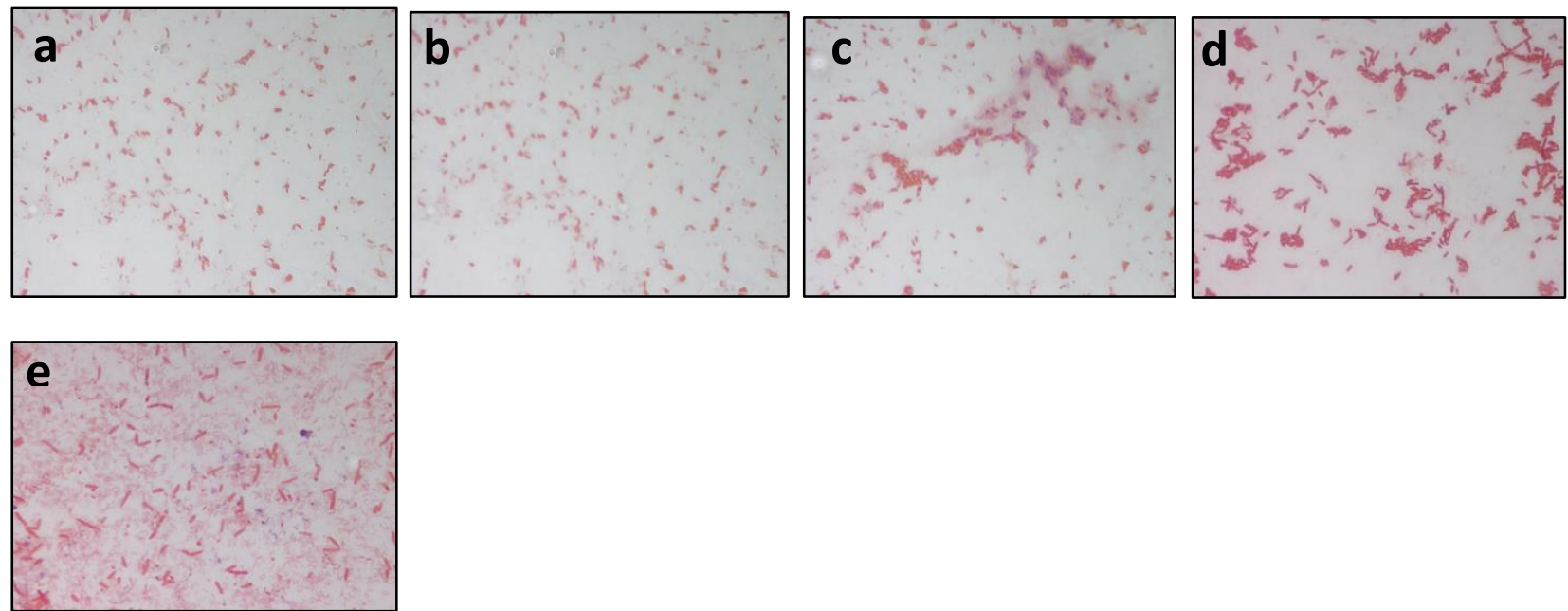

Gambar 2. Pewarnaan Isolat BAL inasua pada MRSA: a. Isolat INS-B1; b. Isolat INS-B2; c. Isolat INS-B3; d. Isolat INS-B4; d e. Isolat INS-B5.

NA digunakan untuk pertumbuhan mayoritas dari mikroba yang tidak selektif, dalam artian mikroba heterotrof. Pada media NA semua bakteri dapat tumbuh baik bakteri GRAM negatif atau positif. Penggaraman pada proses fermentasi memiliki fungsi untuk mencegah pertumbuhan bakteri pembusuk dan mendorong pertumbuhan bakteri asam laktat. Pertumbuhan bakteri dalam fermentasi secara tradisional tidak dapat terkontrol. Maka dari itu, bakteri merugikan seperti bakteri pembusuk, coliform, dan bakteri pembentuk histamin akan tetap tumbuh (Rinto 2010).

Menurut Paludan dan Muller (2001) mikroba dominan di Sikuda inasua adalah bakteri berbentuk batang, GRAM positif dan katalase positif. Satu kelompok bakteri yang memiliki karakteristik ini adalah Bacillus. Bakteri ini dapat ditemukan di tanah dan air, termasuk air laut. Kemampuan untuk membentuk spora menyebabkan Bacillus bisa bertahan dalam kondisi $\mathrm{pH}$ rendah dan salinitas tinggi. Penurunan $\mathrm{pH}$ yang dicapai saja 5.80 memungkinkan bakteri ini bisa tumbuh di Sikuda inasua. Bacillus intoleran di bawah pH 5-5,5 dalam fermentasi ikan.

\section{Kesimpulan}

Berdasarkan hasil penelitian dapat disimpulkan bahwa hasil isolasi Bakteri Asam Laktat dari inasua didapatkan 4 isolat yang tumbuh pada medium MRSA dan hanya 2 isolat yang memiliki karakteristik mikroskopis pewarnaan 
GRAM Positif yaitu INS-A2 dan INS-A4 dengan bentuk Bacillus. Diduga 2 isolat tersebut adalah isolat bakteri asam laktat. Pada media NA (Nutrient Agar) didapatkan 5 isolat yang merupakan bakteri GRAM Negatif dengan bentuk Bacillus.

\section{Daftar Pustaka}

Acton, Q.A. 2013. Advances in Lactobacillaceae Research and Application ed. Scholarly Edition, Georgia, 48.

Alam, M.S., Sarjono P.R., dan Aminin, A.L. 2013.Isolasi Bakteri Selulolitik Termofilik Kompos Pertanian Desa Bayat, Klaten, Jawa Tengah. Chem Info. No.1(1):190-195. http://download.portalgaruda.org/article.php?article=74230\&val=4709

Buckle, K.A. and Edward, R.A. 1978. Ilmu Pangan. UI Press. Jakarta.

Candra, J.I. 2006. Isolasi dan Karakteristik Bakteri Asam Laktat Dari Produk Bekasam Ikan Bandeng (Chanos chanos).Skripsi. Institut Pertanian Bogor : Bogor.

Chen, H. and Hoover, D.G. 2003. Bacteriocins and their food application. Comprehensive Reviews in food science and food safety. doi.wiley.com/10.1111/j.1541-4337.2003.tb00016.x

Dwidjoseputro. 2005. Dasar-Dasar Mikrobiologi. Djambatan: Jakarta.

Hadioetomo, R.S. 1993. Mikrobiologi Dasar Dalam Praktek. Penerbit PT. Gramedia. Jakarta, hal. 106.

Irianto, K. 2006. Mikrobiologi Menguak Dunia Mikroorganisme. Jilid 2. Bandung: CV. YramaWidya.

Jay, J.M. 1996. Modern Food Microbiology. Edisi ke-4. New York (US): Chapman and Hall.

Mahlutte, F., Rachmania, N.M., Suwanto, A., dkk. 2016. Isolation and Characterization of Lactic Acid Bacteria From Inasua. J. of Trop. Biodiv. and Biotech. 1(2):71-76. https://doi.org/10.22146/jtbb.16380.

Nara, S., Ijong, F., Suwetja, I.K., dkk. 2013. Ina sua, a fermented salted fish product from central Moluccas. Aquat Sci. Manag. 1(2):160-164. https://ejournal.unsrat.ac.id/index.php/jasm/article/view/7279

Natsir dan Sartini, 2006. Mikrobiologi Farmasi Dasar. Universitas Hasanudin, Makasar.

Nendissa, J.S. 2013. Pengaruh Penambahan Pediococcus acidilactici F11 Sebagai Kultur Starter terhadap Kualitas Ikan Asin (inasua) Bae (Lutjanus malabaricus). Ekosains. 2(1):39-46. http://bbp4b.litbang.kkp.go.id/jurnaljpbkp/index.php/jpbkp/article/viewFile/84/59

Noonpakde, W., Jumriangrit, P., Wittayakom, K., dkk. 2009. Two-peptide Bacteriocin from Lactobacillus plantarum PMU 33 Strain Isolated from Somfak, a Thai Low Salt Fermentation Fish Product. Asia. Pac. J. Mol. Biol. Biotechnol. 17(1):19-25. https://www.researchgate.net/publication/255610622_Twopeptide_bacteriocin_from_Lactobacillus_plantarum_PMU_33_strain_isolated_from_somfak_a_Thai_low_salt_fermented_fsh_product

Owens, J.D., and Mendoza, L.S. 1985. Enzymically hydrolysed and bacterially fermented fishery product. $J$ Food Technol. 20:273-295. http://doi.wiley.com/10.1111/j.1365-2621.1985.tb00378.x

Paludan and Muller C.P., Madsen, M., Sophanodora, P., dkk. 2002. Fermentation and Microflora of Plaa-som, a Thai Fermented Fish and Fish Product Prepared with Different Salt Concentration. Int..J. Food. Microbiol. 73: 61-70. https://www.ncbi.nlm.nih.gov/pubmed/11883675

Panda, S.H., Ray, R.C., El Sheikha, A.F., dkk. 2011. Fermented Fish and Fish Product. Aquacul Microbiol Biotechnol. 2:132-172.

Pelczar, M.C., Chan, E.C.S and Krieg, N.R. 2008. Microbiology Concepts and Applications. McGraw-HM, Inc., New York.

Plesis, H.W., Dicks, L.M., Pretorius, I.S., dkk. 2004. Identification Lactic Acid Bacteria Isolated From South African Brandy Base Wines. Int. J.Food Microbiol. Vol. 91: 19-29. https://researchers.mq.edu.au/en/publications/identification-of-lactic-acid-bacteria-isolated-from-south-africa

Prescott, L.M., Sherwood, L., Willey, J.M., dkk. 2008. Microbiology 7th edition. USA: McGraw-Hill Book Company. 
Purwadhani, Made, S., dan Endang, S.R. 2007. Stabilitas Thermal Agensia Probiotik L. Acidophillus SNP 2 Terenkapsulasi Metode Ekstrusi Dan Emulsi. Fakultas Teknologi Pertanian Universitas Gadjah Mada Yogyakarta (Hal 1).

Ray, B. 2004. Fundamental Food Microbiology, Third Edition. CRC Press LLC Boca Raton, Florida.

Rahayu, W.P., Suliantari dan Fardiaz. 1992. Teknologi Fermentasi Produk Perikanan Bogor: PAU Pangan dan Gizi. IPB.

Ravishankar, S. 2004. Food Microbiology: a laboratory manual. Food Microbiol. 21(4),489. https://doi.org/10.1016/j.fm.2004.01.008

Rustan, I.R. 2013. Studi Isolasi Dan Identifikasi Bakteri Asam Laktat dari Fermentasi Cabai Rawit (Capsicum frutences L.). Skripsi. Makassar. Fakultas Pertanian Universitas Hasanuddin Makassar.

Saithong, P., Panthavee, W., Boonyaratanakornkit, M., dkk. 2010. Use of Starter Culture of Lactic Acid Bacteria in Plaa-som, a Thai Fermented Fish. J. Biosci. Bioeng. 110(5):553-557. http://linkinghub.elsevier.com/retrieve/pii/S1389172310001945

Singleton and Sainsbury. 2006. Dictionary of Microbiology and Molecular Biology 3rdEdition. John Wiley and Sons Inc. Sussex, England.

Smid, E. J. and Gorris. L. G. 2007. Natural antimicrobials for food preservation. In: M. S. Rahman (Ed.). Handbook of Food Preservation. 2nd ed. CRC Press, New York.

Sujaya, I.N., Ramona, Y., Utami, D.N.M., dkk. 2008. Isolation and Characterization of Lactic Acid Bacteria frim Sumbawa Mare Milk. Jurnal Veteriner.9:52-59. https://ojs.unud.ac.id/index.php/jvet/article/view/3314

Surono, I. 2004. Probiotik Susu Fermentasi dan Kesehatan, PT. Zitri Cipta Karya: Jakarta. Teknologi dan Industri Pangan, 7(2) : 46-5.

Usmiati, S dan Sudono, A. 2012. Teknologi Pengolahan Susu. Balai Besar Penelitian dan Pengembangan Pasca Panen Pertanian Bogor. Bogor.

Wibowo, M.S. 2012. Pertumbuhan dan Kontrol Bakteri. Jurnal Pertumbuhan Bakteri.

Witono., Miryanti dan Yuniarti, L. 2013. Studi Kinetika Dehidrasi Osmotik pada Ikan Teri dalam Larutan Biner dan Terner. Bandung (ID): Lembaga Penelitian dan Pengabdian Kepada Masyarakat Universitas Katolik Parahyangan.

Waluyo, L. 2008. Teknik Metode Dasar Dalam Mikrobiologi. UMM Press, pp. 222-258.

Yousef, A.E and Carolyn C. 2003. Food Microbiology: A Laboratory Manual. Wiley-Interscience, John Wiley and Sons, Inc. Ohiostate University. USA. 223-224. 